\title{
Importance of Computer-Based Accounting Recording in Online Retail Business
}

\author{
S Anggraeni ${ }^{1}$, R Soegoto ${ }^{2}$

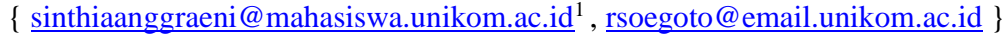 \\ Departemen Manajemen, Universitas Komputer Indonesia, Indonesia ${ }^{1}$, \\ Departemen Manajemen, Universitas Komputer Indonesia, Indonesia ${ }^{2}$
}

\begin{abstract}
The aim of this study is to explain the comparison of the application of computer-based accounting records with manual accounting in online retail. The method used in this study is a comparative method. The results of this study indicate that accounting records as independent variables play an important role in the dependent variable namely online retail and computerbased accounting records which are considered to be more efficient and more organized than manual accounting records. These results are obtained from research on online retailers that have applied accounting records and compared to online retailers that have not carried out computerbased records. So, to find out the importance of computer-based accounting in online retail, businesses will use comparative research methods to get results that show that computer-based accounting is very important role in the business.
\end{abstract}

Keywords: computer-based accounting, retail businesses

\section{Introduction}

Mohammad Hekmati explained that the benefit of using computers in the field of accounting is that it provides convenience in performing accounting functions such as journaling, posting to ledgers, and so on. By using technology to help the work of an accountant, financial statements such as balance sheets, income statements, and others can be presented at the same time [1]. Keoleian explained that accounting plays an important role in the business world. Accounting provides two functions in a company business, namely financial accounting which presents reports about financial status and management accounting which presents a cost analysis that will be used as a basis for decision making in the company and strategic planning company [2]. Eddy Soeryanto Soegoto interpreted the business as being able to be done manually or by using existing technology in conducting its business activities which include aspects of marketing, management, finance, etc. [3]. Anantaran explained that many consumers are turning to online retail because one of the benefits of shopping at online retail is that we can get cheaper prices when compared to the prices in the offline store. It makes the online retail business popular. [4].

Previous papers written by Maziyar Ghasemi focused more on the influence of technology on modern accounting systems [5], while this research focused more on the importance of computer-based accounting records on online retail. In another study by Aysel Guneya, it is explained about the importance of the application of computer-based accounting education since childhood [6]. The difference between that study and this research is that this study explains the importance and benefits for online retailers who have made computer-based accounting records. Other studies written by Fathollah et al and Swaminathan et al presented about business through the internet that is growing very rapidly in the world and has a positive impact on sellers $[7,8]$ while this research is more about the more specific internet business that is online retail. Speaking of business, Ramune Ciarniene in his research revealed that the things that must be analyzed on the competitiveness of technology-based businesses are four different levels but are still interrelated, namely the company level, industry level, country level, and global level [9], while this research more focused on recording accounts that are computer-based. In addition, in a study conducted by Anna Brzozowska, she explained the behavior of a seller who conducts his business online [10], while this research focuses more on recording transactions on computerbased online retailers. 
The purpose of this study is to compare the application of manual accounting records with computer-based accounting records and the benefits of computer-based recording on online retail. The method used in this study is a comparative method by comparing two online retailers who have done computer-based accounting records and manual recording.

\section{Material and Methods}

The method used in this study is a comparative method that compares online retailers who have done computer-based accounting records with online retailers that still use manual recording so that it can be identified how important computer-based accounting records are in online retail businesses. This research was conducted in Palupicorp as an online retailer that has not made computer-based accounting records from October 1 to October 102018 and Socks.so which is an online retailer that has done computer-based accounting records of transactions from October 1 to October 52018 using multilevel 3 level inverter and multilevel 2 level inverter.

\section{Results and Discussion}

Accounting is very important to be applied in activities related to the economy. There are many accounting activities found in everyday life, but we do not realize that we are carrying out accounting activities. An example of the application of accounting in everyday life is when a seller records the transactions that occur to see or control the finances of the business where he lives in. It shows that the seller is carrying out accounting activities. If accounting is applied correctly in everyday life, then matters related to finance will be more organized, neat, and easy to understand because that is the function of accounting in human life.

Accounting is very closely related to a seller because accounting records are very important for sellers to see their business financial activities. An example of a seller who conducts accounting recording activities in his business is Palupicorp online retail stores (Figure 1).

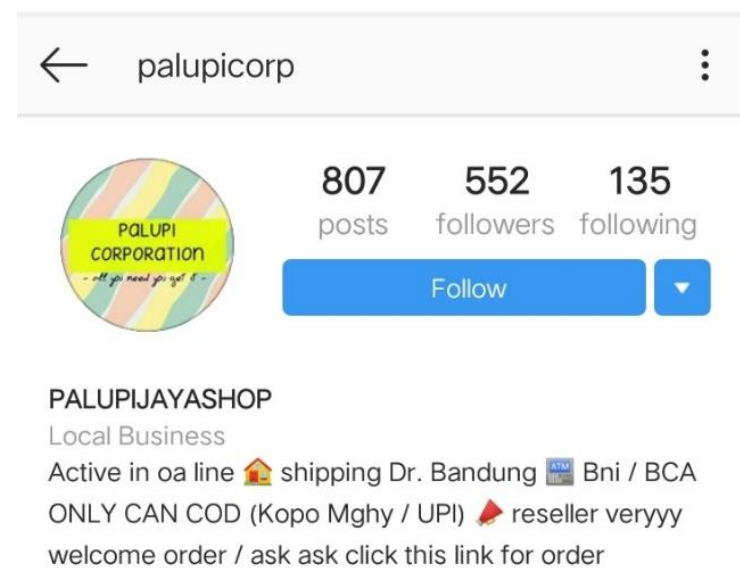

Fig 1. Profile Page of Palupicorp.

Figure was adopted from www.Instagram.com/ on Des $29^{\text {th }} 2018$

In the profile page, there is a section that displays various items sold by Palupicorp so that buyers can directly see the products offered. There are various products sold by Palupicorp including beauty products such as face masks, perfumes, sandals, bags, clothes, cake, wallets, etc. Payments applied in this business are non-cash payments (see Figure 2). 


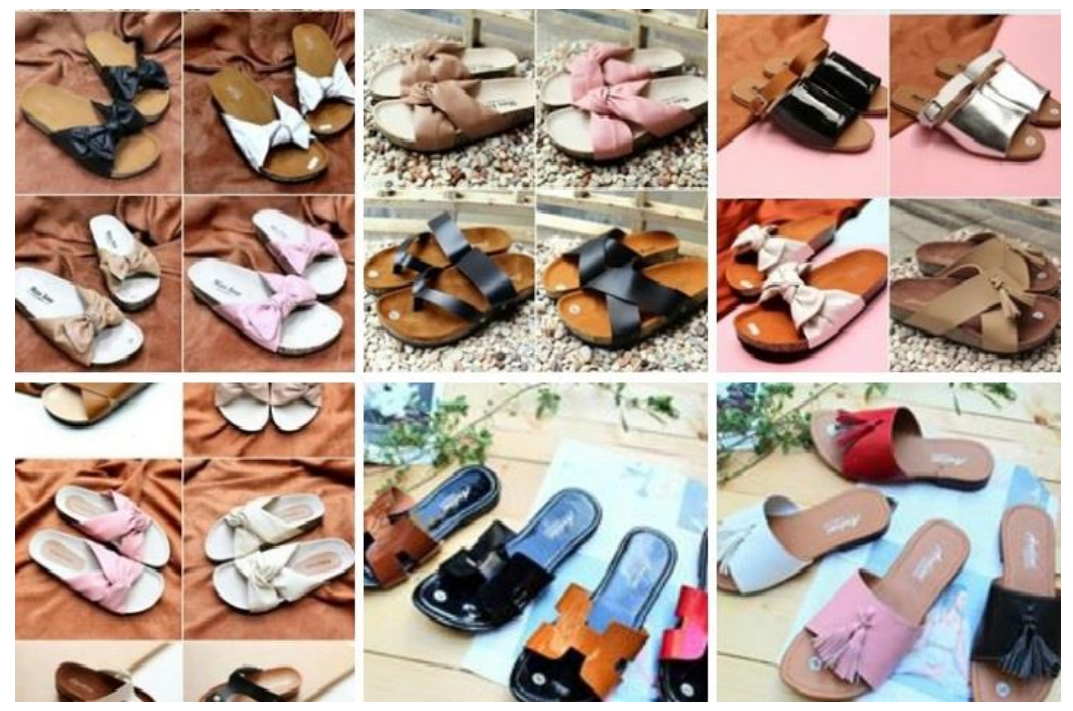

Fig 2. Product by Palupicorp.

Figure was adopted from www.Instagram.com/ on Des $29^{\text {th }} 2018$

In conducting its business, Palupicorp still does accounting manually, meaning it still records income and expenses on paper. They have not done computer-based recording because the owner argues that he can still handle his financial problems manually and he also records them alone without being helped by others. However, this was considered less effective and efficient because the recording was carried out long enough and could produce waste paper and the results were not organized because they were scattered (see Figure 3).

\begin{tabular}{|c|c|c|c|c|c|c|c|}
\hline & & & \multicolumn{2}{|c|}{ Cake } & & & \\
\hline & & & \multicolumn{2}{|c|}{ First Week Of Sept } & & & \\
\hline & Monday & Tuesday & Wednesday & Thursday & Friday & Saturday & Sunday \\
\hline Income & $\operatorname{Rp} 365.000$ & $\operatorname{Rp} 248.000$ & Rp 265.000 & Rp 170.000 & Rp485.000 & Off & $\operatorname{Rp} 225.000$ \\
\hline Expence & $\operatorname{Rp} 248.000$ & Rp 185.000 & Rp 198.000 & Rp 125.000 & Rp320.000 & Off & Rp 165.000 \\
\hline
\end{tabular}

Fig 3. Recording of Palupicorp Transactions.

Figure was adopted from www.Instagram.com/ on Des $29^{\text {th }} 2018$

Meanwhile, the online retail that has carried out computer-based accounting records is socks.so. They made computer-based accounting records on the income flow and the flow of expenses that occur in the business. Payments made in this business no longer use cash but have changed to non-cash money by transferring the money (Figure 4).

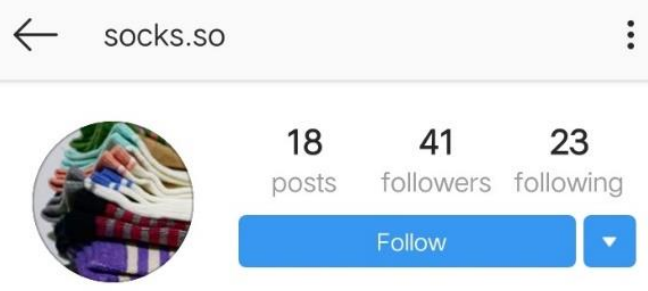

\footnotetext{
CHEAP SOCKS Rp 7.000/PAIR

Clothing (Brand)

Cheap Socks \& motive. IDR 7.000 / pair. Order? Line

@zwj3892b (using@). Payment? BCA

SEE ORIGINAL
}

Fig 4. Profile Page of Socks.so.

Figure was adopted from www.Instagram.com/ on Des $29^{\text {th }} 2018$ 
Same as Palupicorp display, in the socks.so profile, items sold by socks.so in the form of motive and plain socks intended for all people such as old, young, female and male, and so on are displayed. This shop only focuses on one product, namely socks, but the main target of this online retail store are teenage girls who are dressed in the current era. However, it does not rule out the possibility of men wearing it (see Figure 5).

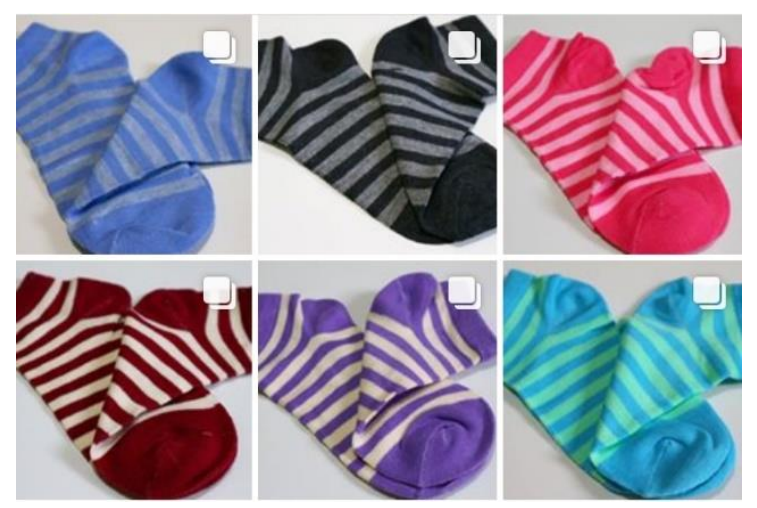

Fig 5. Product by socks.so.

Figure was adopted from www.Instagram.com/ on Des $29^{\text {th }} 2018$

Although this online retail store is still relatively new, it has used computer-based accounting records but still in simple form. What they do is record business expenses and income. They have made use of existing technology so that the recording is made easier and neat. In addition, computer-based accounting records are also more efficient because they can reduce paper waste that has been polluting the environment nowadays. The owner argues that by carrying out computer-based accounting records, the financial records become neater and organized and it reduces the risk of losing records (see Figure 6).

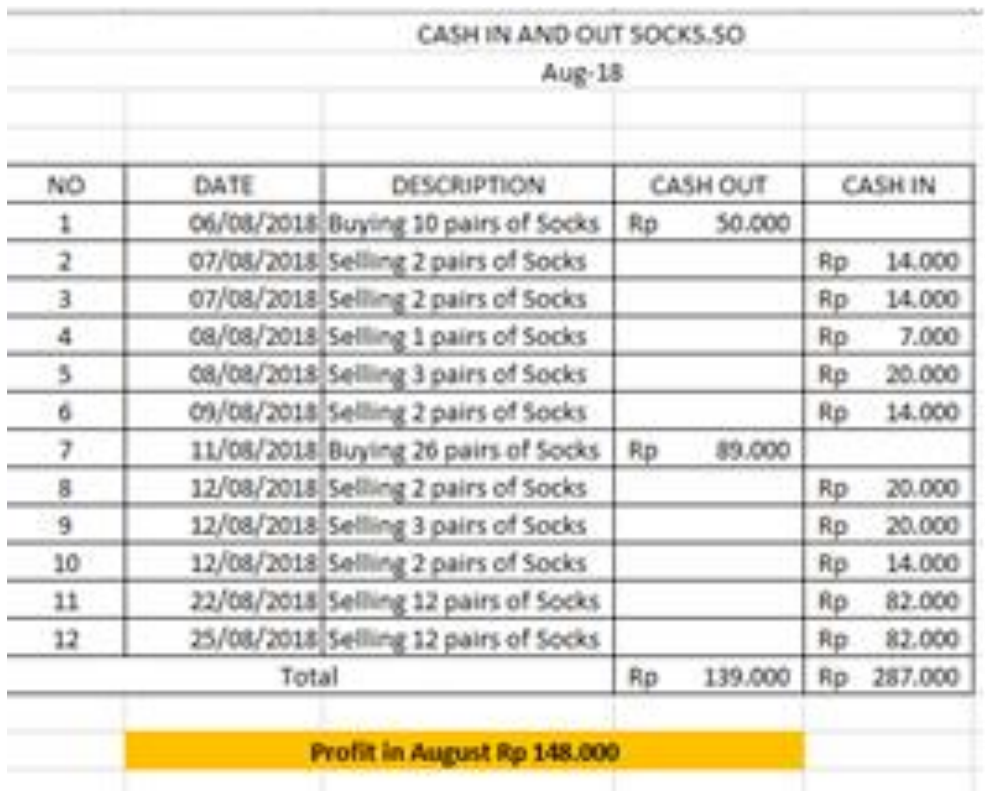

Fig 6. Recording of Socks.so Transactions.

Socks.so has felt the benefits obtained from the use of technology in carrying out accounting activities, especially in recording income and business expenses. So, it can be seen clearly how much profit is gained in August. Computer-based recording is easier to use and more efficient because the power used is not as much energy when manually recording using pencils or pens and paper. 


\section{Conclusion}

Computer-based accounting records are more useful and important to be applied by online retail businesses to make it easier to manage financial transactions that occur when compared to online retailers who have not used computers in recording their business accounting. Computerbased accounting can provide convenience in processing and presenting financial statements as well as making reports neater and organized so that it is easy to understand while in accounting records that have not used computers, the data collected is not organized and scattered, and the risk of missing data is greater due to still using paper. In addition, the use of computer-based accounting can reduce paper waste that can pollute the environment. Therefore computer-based accounting is important to be used in online retail even though the business is still small.

\section{Acknowledgment.}

We would like to give thanks to Mr. Edy Soeryanto Soegoto as the mentor and all parties who support this research.

\section{References}

[1] Hekmati M., Barvayeh E., Hashemi M. : The Capabilities of Computers in Accounting. ProcediaSocial and Behavioral Sciences, 28, pp. 932-936, (2011)

[2] Keoleian, G. A. : Product life cycle assessment to reduce health risks and environmental impacts. Elsevier. (1994)

[3] Soegoto, Eddy Soeryanto.. Entrepreneurship-MenjadiPembisnisUlung. : PT Elex Media KomputindoKompasGramedia, Jakarta, (2014)

[4] Balakrishnan, A., Sundaresan, S., \& Zhang, B. : Browse-and-Switch: Retail-online competition under value uncertainty. Journal of Production and Operations management,23(7), pp. 1129-1145, (2014)

[5] Ghasemi M., Shafeiepour V., Aslani M., Barvayeh E. : The impact of Information Technology (TI) on Modern Accounting Systems. Procedia-Social and Behavioral Sciences, 28, pp. 112-116, (2011)

[6] Guney A. : Role of Technology in Accounting and E-Accounting. Procedia-Social and Behavioral Sciences, 152, pp. 852-855, (2014)

[7] Swaminathan, J. M., \&Tayur, S. R. : Models for supply chains in e-business. Journal of Management Science, 49(10),pp. 1387-1406. (2003)

[8] Fathollah, M., Taham, F., \&Ashouri, A. : Developing a Conceptual Framework for Simulation Analysis in a Supply Chain Based on Common Platform (SCBCP). Journal of applied research and technology, 7(2), 163-184. (2009)

[9] Ciarniene R., Stankeviciute G. : Theorical Framework of E-Business Competitiveness. ProcediaSocial and Behavioral Sciences, 213, pp. 734-739, (2015)

[10] Brzozowska A., Bubel D. : E-Business as a New Trend in The Economy. Procedia-Computer Science, 65, 1095-1104, (2015) 